\title{
Gender Inequality in University Administration and Services
}

\author{
Sofía Estelles-Miguel ${ }^{1}$, Antonio Navarro-García ${ }^{2}$, Marta E. Palmer Gato ${ }^{1} \&$ José Miguel Albarracín Guillem $^{1}$ \\ ${ }^{1}$ Universitat Politècnica de València, Department of Business Organization, Edifici 7D 46020 Valencia, Spain \\ ${ }^{2}$ Universidad de Sevilla, Departamento de Administración de Empresas y Marketing, Avda Ramón y Cajal 1, 41018, \\ Seville, Spain \\ Correspondence: Sofía Estelles-Miguel, Universitat Politècnica de València, Department of Business Organization, \\ Edifici 7D 46020 Valencia, Spain. Tel: 34-96-387-7007-Ext.76841. Fax: 963879779. E-mail: soesmi@omp.upv.es
}

Received: November 15, 2014

Accepted: December 15, 2014

Online Published: December 16, 2014

doi:10.5430/bmr.v3n4p89

URL: http://dx.doi.org/10.5430/bmr.v3n4p89

\begin{abstract}
This article addresses inequalities between men and women at work. Inequalities in job access and career progression are addressed. The article reviews literature on equal opportunities at work. A case study of administrative and services staff at a public university in Valencia (Spain) is then presented. The case study assesses the current reality of gender inequality in Spanish public institutions. Spanish public universities hire candidates with the best results in public examinations. Men and women should therefore enjoy equal access to jobs at Spanish public universities. The reality, however, is not so.
\end{abstract}

Keywords: Equal opportunities, Occupational segregation, Vertical segregation, Horizontal segregation, Glass ceiling

\section{Introduction}

According to the ILO (2010), occupational segregation by gender is one of the most common features of developed countries' labour markets. Like other countries in the Mediterranean arch, Spain has historically had one of the highest levels of segregation, with this level increasing during the nineties (Cáceres et al. 2004, Cebrián et al. 2008). In addition, scholars have found evidence of the increase of occupational segregation by gender in Spain (García et al. 2011). This increase has taken place against the backdrop of technological change that has intensified demand for qualified work, an area with which women now identify to a greater degree (Iglesias et al. 2010), and sectorial change, whereby historically male-dominated industrial jobs are replaced by women-dominated services jobs (Iglesias et al. 2009).

Differences in pay and access to jobs may reflect differences in candidates' qualifications or capabilities, but these differences may also reflect discrimination against certain demographic groups based on skin colour, sex, religion, race and so forth, regardless of education, work experience or skills. If these disparities owed to differences in productivity, the labour market would be operating efficiently. Conversely, if these differences principally owed to discrimination according to characteristics such as race or sex, then the labour market would be operating inefficiently.

Some theories refer to gender differences in human capital, from either offer (Becker, 1965) or demand (Becker, 1971) perspectives. Besides these theories, other theories have emerged that stress preferences in men and women. Identity economics (Akerlof \& Kranton, 2000), pollution theory (Goldin, 2002) and the theory of preference discrimination exemplify such theories (Bender et al. 2005).

In its annual report, the World Economic Forum publishes the Global Gender Gap Report (Hausmann et al. 2010). The aim of this index is to provide the rate at which the gender gap is closing in 130 countries. The index comprises four critical inequality areas. In countries with greater gender equality, inhabitants enjoy better well-being, and social cohesion and integration. There is a correlation between gender equality, competitiveness and GDP growth (Hausmann et al. 2006, 2010). Globally, in health and education the gap between women and men is closing more rapidly than in areas of economic participation, opportunities and decision-making.

\section{Objective and method}

We analysed gender inequality in administrative and services jobs in a Spanish public university. To do so, we employed a research method based on a bibliographical review. This method allowed us to frame the problem and then analyse the current situation in a specific Spanish university. We took one Spanish public university as the sample. We analysed the number of male and female staff in administrative and services jobs according to scale, 
classification and set of criteria.

\section{Types of discrimination}

According to Constitutional Act 3/2007 of 22 March for effective equality between women and men, there are two types of discrimination:

1) "Direct discrimination is regarded to be a situation where one person is treated less favourably on the grounds of sex than another is, has been or would be treated in a comparable situation." This type of discrimination covers any type of unfavourable treatment of women regarding pregnancy and maternity. Direct discrimination also covers pay differences between men and women who do the same job, as stated in the Amsterdam Treaty (1997).

2) "Indirect discrimination is regarded to be a situation where an apparently neutral provision, criterion or practice would put persons of one sex at a particular disadvantage compared with persons of the other sex, unless that provision, criterion or practice is objectively justified by a legitimate aim, and the means of achieving that aim are appropriate and necessary." For instance, this type of discrimination applies to the following situations:

a. Men and women are allowed to apply for jobs for which only men or only women will be selected.

b. Salaries are equal within the same job category, but women are more numerous in lower paid categories.

c. Women forego promotions at work because they encounter genuine difficulties in reconciling work and family responsibilities. Because women remain the main carers of the family, work schedules with working lunches or long hours hamper women's professional careers. Reconciliation of work and family responsibilities is one of the principal reasons why women, rather than men, ask for a reduction in hours or request leave to care for children.

\section{Occupational segregation}

Segregation in the labour market refers to the representation of women and men in different occupations (i.e., they work in different sectors and have different jobs). Female workers systematically cluster in occupations with greater instability, lower pay and lower recognition.

Women have notably increased their participation in the paid labour market. Nevertheless, women tend to experience higher unemployment rates than men, work more often than men in temporary or part-time jobs, and suffer pay discrimination, segregation and lower chances of promotions than men do. Hence, equality has not accompanied the increase in women's participation in the paid labour market. In fact, women and men have unequal positions in the paid labour market (Rubio, 2008). Recent gender research has speculated that occupational gender segregation is reflected in the gendered aspects, self-expressive career decisions of men and women (Cech, 2013).

Several authors have investigated both occupational segregation and segregation by economic sector (Niederle et al. 2013). Anker (1998) provided evidence that occupational segregation by gender is common around the world and argued that segregation could be explained by three theories: human capital differences (whereby women would be less qualified for certain occupations than men would), labour market segmentation (which posits the reduction of salaries in female-based occupations) and greater responsibility in caring for children.

Around 2007, segregation in Spain changed. This change was accompanied by shifts in arguments that maintain inequality between men and women in the labour market (Dueñas Fernández et al. 2013). Research has highlighted two forms of occupational segregation by gender: horizontal segregation and vertical segregation. In all EU countries, both types of segregation are present, although the degree of segregation varies (European Commission, 2009).

\subsection{Horizontal segregation}

Horizontal segregation (Anker, 1998) refers to situations whereby female workers cluster in activities traditionally linked to women. In Europe, women predominate in five sectors: health assistance, social services, education, public administration and retailing (Rubio, 2008). According to Torns et al. (2007), this distribution has not changed in the last 30 years.

Cebrián and Moreno (2008) showed that more than half of employed women in Spain are clustered in five branches of the services sector and that nearly half of employed women work in six low-qualification occupations. The report indicates that the large increase in female employment has been accompanied by any increase in occupational segregation, thereby implying that stereotypes regarding "female" and "male" occupations remain. 


\subsection{Vertical segregation}

Morrison \& Von Glinow (1990) first defined the glass ceiling as a barrier "that appears invisible but is strong enough to hold women back from top-level jobs merely because they are women rather than because they lack job-relevant skills, education, or experience. From this first time, this definition appears in many other publications (Morrison et al., 1992, Powell \& Butterfield, 1994 and US Department of Labor, 1991 and 1995) and starts to become relevant to the present day. Top management jobs should depend on candidates' knowledge, effort and skills. In reality, however, such jobs remain out of reach for many women in management positions. Vertical segregation affects all types of work because "whatever the sector, even the most women-dominated sectors, the proportion of women drops as they move up in the hierarchy, which means that the presence of women who are in powerful positions and assume responsibility at work is minimal" (Sarrió et al., 2002, 56). Despite exponential growth in women's average education level attained, vertical segregation remains unchanged (Rubio, 2008).

Numerous studies have highlighted the main barriers facing women seeking promotions to management positions (Catalyst, 2004; Chinchilla et al., 2005 and Mateos de Cabo et al., 2007).

Table 1. Barriers in the promotion of women in different contexts. Source: Barbera et al. (2011)

\begin{tabular}{|c|c|}
\hline Europe & Spain \\
\hline $\begin{array}{ll}\text { - } & \text { The existence of stereotypes. } \\
\text { - } & \text { Lack of visibility in top positions. } \\
\text { - } & \text { Lack of experience. } \\
\text { - } & \text { Commitment to personal life. } \\
\text { - } & \text { Social barriers (reconciliation of } \\
\text { career with personal life). } \\
\text { - } & \text { Psychological perception of } \\
\text { suitability for management } \\
\text { positions. }\end{array}$ & $\begin{array}{l}\text { - Occupational segregation by gender } \\
\text { in the labour market. } \\
\text { - } \quad \text { Pacts between men or peers. } \\
\text { - Management stereotype of } \\
\text { organisational culture with features } \\
\text { associated with the role of men, } \\
\text { commitment to the organisation, } \\
\text { career success and work dedication. } \\
\text { - Division of productive/reproductive } \\
\text { work. } \\
\text { - The "concrete ceiling". }\end{array}$ \\
\hline
\end{tabular}

Chinchilla et al. (2005) argues that the "concrete ceiling" (Note 1) can be viewed from two perspectives. First, some women reject strict or demanding management positions because they foresee potential difficulties in reconciling their careers and personal lives. Second, some women resign from management positions because they experience greater pressure in this type of position than their male colleagues do. Some studies, such as that of Estebaranz (2004), have shown that management positions imply different costs for businesses depending on whether women or men fill these positions.

\section{Case study}

The university for which we gathered data has had an equality plan since 2013. The main aspects of this plan are equal participation by men and women, policies aimed at increasing the presence of women in public and governance positions, and active participation in the university community.

To perform the current analysis we gathered data from the university's intranet. The university's equality unit collects data on equality. Although the unit shared these data with us, we have not used them in the present study to respect confidentiality. Importantly, in public functions, the principles of equality, merit and capability take precedence.

Data show that the presence of men and women is balanced because neither men nor women occupy more than $60 \%$ or less than $40 \%$ of jobs. Although data show an increase in female presence from 2005 to 2014, there are small imbalances by job category. Some categories such as administration, health assistance, auxiliary services, archiving and library services and museum jobs are women dominated. Other categories are male dominated, although the presence of women has increased in these categories. Such categories include programmers, and junior and senior laboratory technicians.

In the present study, we analysed the structure of administration and services staff in all university departments to show the gender distribution of jobs. When we performed the analysis, there were 271 staff, of whom 151 were men and 120 women. 


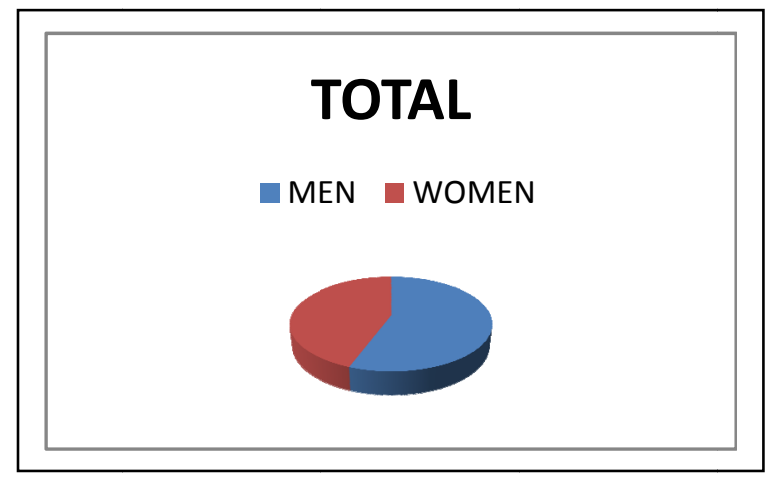

Figure 1. Men and women in the university administration and services staff. Source: Authors' own work.

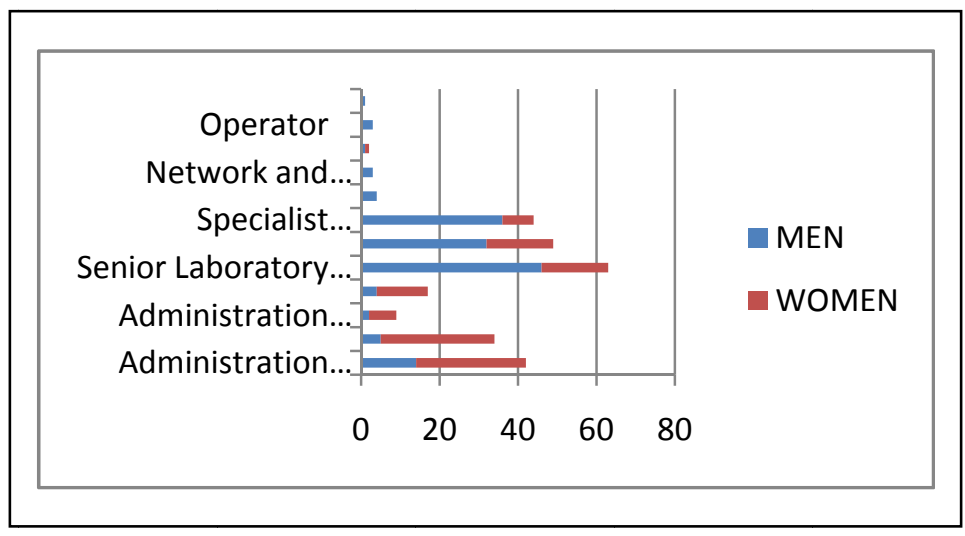

Figure 2. University administration and services staff structure. Source: Authors' own work.

Some categories are highly male dominated. Such categories are programs analyst, network and systems analyst, operator and second official of laboratory, although these categories are not representative because very few people are employed in these positions. Some categories are partially male dominated. An example of such a category is that of laboratory technicians. No category is completely women dominated, although there are some women-dominated categories such as administration unit head, administrator, administration department head, secretary. Finally, there are some categories where no women occupy positions.

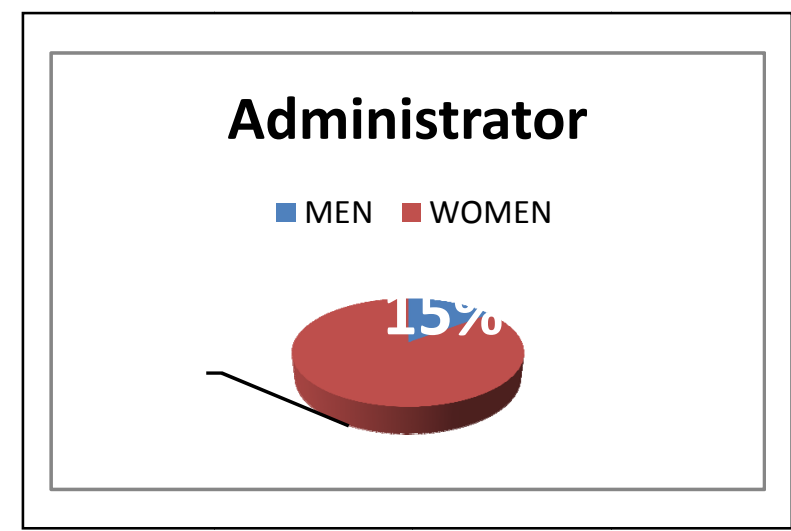

Figure 3. Gender distribution in the most women-dominated category. Source: Authors' own work 


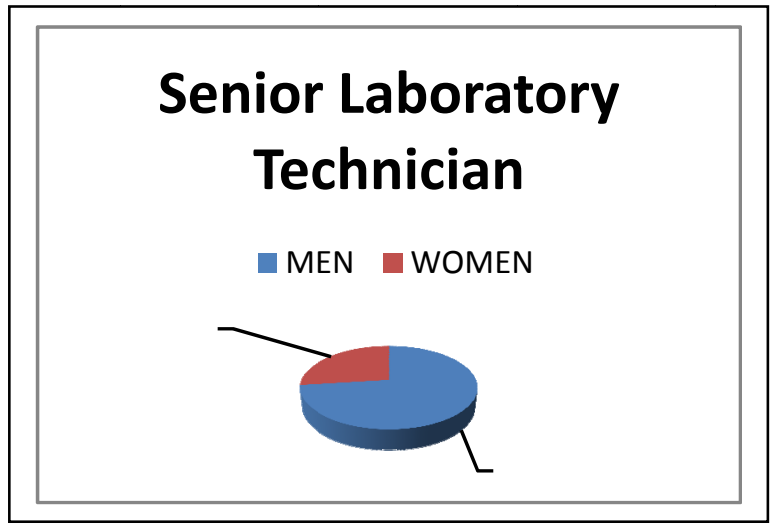

Figure 4. Gender distribution in one of the most male-dominated categories. Source: Authors' own work

\section{Conclusions}

Throughout the present study, we have attempted to provide insight into occupational segregation by gender and the reasons why it occurs. Currently, the number of organisations with social awareness is growing. These organisations' objectives are not only to maximize profits, and these organisations' social responsibility involves human resources management that stresses greater gender equality.

Although, in theory, public administration should embody all kinds of equality better than any other organisation, and despite laws supporting equality, results show that, in reality, this is not the case. There is still much to be done to achieve gender equality in these organisations.

Business and society are prepared for legislative changes that eliminate obstacles and enable women to access professions and positions for which they are well prepared. Organisations, under the umbrella of corporate social responsibility, have already started to develop actions to fight against gender inequality. Nevertheless, much progress is still needed.

Obviously, sociocultural changes do not occur instantaneously; they need time. Nevertheless, so that these advantages in theory can become a reality, it is first essential for organisations themselves to explicitly commit to equality, including in their values. Second, there must be coherence between these businesses' values and practices.

In Spain, occupational segregation and sector segregation are more intense for women than they are for men and are greater among highly educated people. Hence, improving women's education level does not necessarily lead to less occupational segregation and a smaller pay gap. Substantial equality requires the adoption of a variety of strategies; even in an institution that should be exemplary (i.e., universities), inequalities - sometimes large inequalities remain. The establishment and execution of measures does not depend only on businesses or governmental organisations. Without real conviction, such measures are futile.

\section{Acknowledgments}

The authors acknowledge the financial support from the project PAID-06-12 (Sp 20120792) from Universitat Politècnica de València. Also, the authors recognize the support by Ana del Carmen Alventosa Escorcia as a coordinator of the fieldwork research.

\section{References}

Akerlog, G. \& Kranton, R. (2000). Economics and Identity. The Quarterly Journal of Economics, CXV, No3, pp. 715-753. http://dx.doi.org/10.1162/003355300554881

Alventosa Escorcia, A. \& Estelles-Miguel, Sofía (2014). Trabajo Final de Carrera: Campaña de Sensibilización de Igualdad para el Personal de Administración y Servicios de la Universidad Politécnica de Valencia.

Anker, R. (1998). Gender and Jobs: Sex Segregation of Occupations in the Wordld. International Labor Organization (ILO), Geneva.

Barberá, T., Dema, C.M., Estelles-Miguel, S. \& Devece C. (2011). Las (des)igualdad entre Hombres y Mujeres en el Mercado laboral: La Segregación Vertical y Horizontal. $5^{\text {th }}$ International Conference on Industrial Engineering and Industrial Management, pp. 986-995.Cartagena.

Becker, G. (1965). A Theory of the Allocation of Time, Economic Journal, Vol 75, B 299, pp. 493-517. 
Becker, G. (1971). The Economics of Discrimination, $2^{\mathrm{a}}$ Ed. University of Chicago Press. Chicago.

Bender, K.A., Donohue, S.M. \& Heywood, H.S. (2005). Job Satisfaction and Gender Segregation, Oxford economic Papers, Vol.57, pp. 479-496. http://dx.doi.org/10.1093/oep/gpi015

Cáceres, J.L., Escot, L. \& Sainz, J. (2004). La Segregación Ocupacional Sectorial de la Mujer en el Mercado de Trabajo Español. Documento de Trabajo. Facultad CC.EE. Universidad Complutense de Madrid/ 2004-006 Madrid.

Cébrian, I. \& Moreno, G. (2008). La Situación de la Mujeres en el Mercado de Trabajo Español: Desajustes y Retos. Revista de Economía Industrial, No 367, pp. 121-137.

Cech, E.A. (2013). The Self-Expressive Edge of Occupational Sex Segregation 1. American Journal of Sociology, Vol. 119, No3, pp. 747-789. http://dx.doi.org/10.1086/673969

Chinchilla, N., Poelmans, S. \& León, C. (2005). Mujeres Directivas bajo el Techo de Cristal. International Center of Work and Family. Disponible en http://insight.iese.edu/es/doc.asp?id=00435\&ar=6.

Dueñas Fernández, D., Iglesias Fernández, C. \& Llorente Heras, R. (2013). La Segregación Laboral en las Regiones Españolas durante el Periodo 1996-2010. Investigaciones Regionales, № 27, pp. 91-113.

Estebaranz, A. (2004) Observatorio e Igualdad. Andaluzas Ayer, Hoy y Mañana. Abriendo Caminos. Diputación de Córdoba.

Comisión Europea (2009). Eurobarómetro de la Comisión Europea. Igualdad de Sexos en la UE en 2009. Disponible en http://ec.europa.eu/public_opinion/archives/ebs/ebs_326_fact_es_es.pdf

Fuller, A. (2005). The Gendered Nature of Apprenticeship: Employers'and Young People's Perspectives. Education + Training, Vol. 47, $\mathrm{N}^{\mathrm{o}}$ 4/5, pp. 298-311.

García, I., García, G. \& Montuenga, V.M. (2011). Segregación Ocupacional por Género en Aragón. Documento de trabajo 56/2011 FUNDEAR.

Goldin, C. (2002). A Pollution Theory of Discrimination: Male and Female Differences in Occupations and Earnings, Working Paper 8985, NBER.

Iglesias, C., Llorente, R. \& Dueñas, D. (2009). La Expansión de los Servicios y la Transformación del Empleo en España, Papeles de Economía Española, N 120, pp. 28-43.

Iglesias, C., Llorente, R. \& Dueñas, D. (2010). Diferencias de Género en el Empleo TIC, Cuadernos de Economía, Vol.33, No92, pp. 105-138.

Hausmann, R., Tyson, L.D. \& Zahidi, S. (2006). The Global Gender Gap Report 2006. World Economic Forum. Geneva, Switzerland. Disponible at http://www3.weforum.org/docs/WEF_GenderGap_Report_2006.pdf

Hausmann, R., Tyson, L.D. \& Zahidi, S. (2010). The Global Gender Gap Report 2010. World Economic Forum. Geneva, Switzerland. Disponible at http://www3.weforum.org/docs/WEF_GenderGap_Report_2010.pdf

Hymowitz, C. \& Schellhardt, T.D. (1986). The Glass Ceiling Special Report on the Corporate Woman. The Wall Street Journal, 24 march.

Kmec, J.A. (2005). Setting Occupational Sex Segregation in Motion. Work and Occupations, Wol. 32, No3, pp. 322-354. http://dx.doi.org/10.1177/0730888405277703

Ley Orgánica 3/2007, de 22 de marzo, Para la Igualdad Efectiva de Hombres y Mujeres.

Morrison, A. \& Von Glinow, M.A. (1990). Women and minorities in management. American Psychologist, Vol. 45, pp. 200-208. http://dx.doi.org/10.1037/0003-066X.45.2.200

Morrison, A., White, R. \& Van Velson, E. (1992). Breaking the Glass Ceiling: Can Women Reach the Top of America's Largest corporations? 2 ${ }^{\mathrm{a}} \mathrm{Ed}$., Addison-Wesley.

Niederle, M., Segal, C. \& Vesterlund, L. (2013). How Costly is Diversity? Affirmative action in Light of Gender Differences in Competitiveness. Management Science, Vol 59, $\mathrm{N}^{\circ} 1$, pp. 1-16. http://dx.doi.org/10.1287/mnsc.1120.1602

OIT (2010). Employment Trends for Women. January 2010, International Labor Organization, Ginebra. 
Powell, G. \& Butterfield, D. (1994). Investigating the "glass ceiling" phenomenon: An empirical study of actual promotions to top management. Academy of Management Journal, Vol. 37, pp. 68-86. http://dx.doi.org/10.2307/256770

Rubio, F. (2008). La Bastida. Desigualtats de Gènere. Mercat de Treball. Fundació Surt. Barcelona.

Sarrió, M., Barberá, E., Ramos, A. \& Candela, C. (2002). El Techo de Cristal en la Promoción Profesional de las Mujeres. Revista de Psicología Social, Vol. 2, $\mathrm{N}^{\circ}$ 40, pp. 167-182. http://dx.doi.org/10.1174/021347402320007582

Torns, T., Carrasquer, P., Parella, S. \& Recio, C. (2007). El Treball de les Dones a Catalnya: Mites I Certeses. Institut Català de les Dones, Col. Estudis, n². Barcelona.

Tratado de Amsterdam. (1997). http://www.europarl.europa.eu/topics/treaty/pdf/amst-es.pdf. Date (06/08/2014).

US Departament of Labor. (1991). A Report on the Glass Ceiling Initiative. Washington, DC. Govermment Priting Office.

US Departament of Labor. (1995). Good for Business: Making full use of the nation's human capital. Washington, DC. Govermment Priting Office.

\section{Note}

Note 1. Certain authors who consider the "concrete ceiling" a different barrier from the "glass ceiling" have claimed that some women decide to resign when faced with extreme, disproportionate pressure (Chinchilla et al., 2005, Hernández Ruiz et al, 2008). 